\title{
A Single Past and Multiple Memory Techniques: Remembering the Cold War Period in the Cultural Landscape of the Hungarian Part of the Fertö/Neusiedlersee UNESCO World Heritage Site
}

\section{The Cultural Landscape of the Fertő/Neusiedlersee Region in Hungary}

The Fertö/Neusiedlersee lake region is a transboundary cultural landscape in Austria and Hungary. It has a long, rich history of diverse communities which have been separated not just by the Austrian/Hungarian state border but also, for four decades, by the Iron Curtain. The "reunification" of the area has been facilitated by diverse natural and cultural protection projects instituted on the local and international levels. These projects started with bilateral agreements in the 1970 s, which were continued in the framework of the 1971 Convention on Wetlands of International Importance (the Ramsar Convention), the European Union's Phare program, and the UNESCO World Heritage Convention. Phare was initially launched in 1989 to assist in the postcommunist restructuring of the economies of Poland and Hungary. The concept of a "cultural landscape" was introduced by UNESCO in 1992 to emphasize the value of the harmonious coexistence of humanity and nature in the classic agricultural lifestyle and other contexts. The UNESCO World Heritage Committee recognized the Fertő/Neusiedlersee area as a protected cultural landscape in $2001 .^{1}$

The Lake Fertő/Neusiedler is a lowland saline lake located 114 meters above sea level. It has dried out many times in its history, and its current status as a lake is a diminished form of the sea which existed there earlier. The lake and its surroundings have significant environmental value due to their climate, soil, and reed vegetation, especially for migrating birds. Built elements of the region's heritage include vernacular architecture as well as noble palaces from the eighteenth and nineteenth centuries. The region is rich in intangible cultural heritage elements as well, for instance, works by the famous composer Joseph Haydn that were commissioned there by Prince Esterházy and the knowledge and practice of the local people in the fields of animal husbandry and cottage industries.

The Ferto/Neusiedlersee cultural landscape is located on the track of the former Iron Curtain, which defined the local population's social and economic possibilities for almost half a century. On the Hungarian side, restrictions on the residents' movement were introduced. New technical equipment, such as watchtowers, mines, and soldiers were added to the border area in the mid-twentieth century. Interestingly, soldiers

1 “Ramsar site of Neusiedlersee, Seewinkel \& Hanság," Ramsar Sites Information Service, https:// rsis.ramsar.org/ris/271; "The PHARE Programme and the enlargement of the European Union," European Parliament, http://www.europarl.europa.eu/enlargement/briefings/33a2_en.htm; UNESCO, Convention Concerning the Protection of the World Cultural and Natural Heritage (Report of the 25th session of UNESCO World Heritage Committee, Helsinki, Finland, 11-16 December 2001), 41-42, https://whc.unesco.org/archive/2001/whc-01-conf208-24e.pdf. 


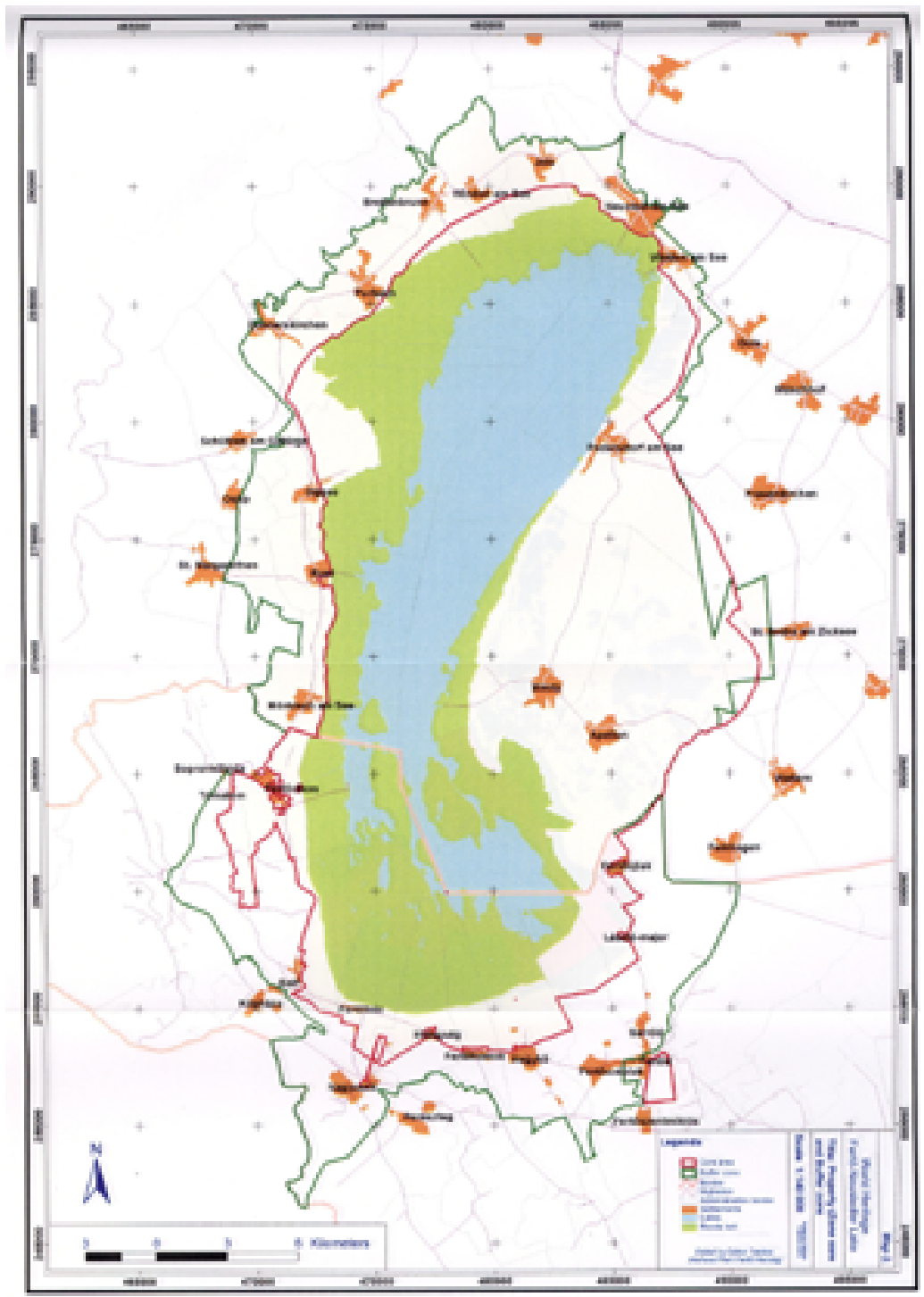

Figure 1. Map of the Fertő/Neusiedlersee Cultural Landscape. Source: United Nations Educational, Scientific and Cultural Organization, https://whc.unesco.org/en/list/772/ multiple=1\&unique_number=913. 
assigned to the border region were mainly young men from other parts of Hungary. Especially after 1955, when Austria's independence was reestablished, Soviet soldiers were removed over the border and settled on the Hungarian side. Ironically, in certain cases they used the same bases as the Nazi German forces who had occupied Hungary during World War II. These units of foreign soldiers were not tasked with influencing local issues but with preparing for a possible attack from the West. Accordingly, they usually stayed on their bases, which made their activities mysterious to the local population. $^{2}$

Border protection sometimes resulted in fatal shootings of local residents and economic damage from weed-killing chemicals that were used in the border zone, destroying the neighboring fruit gardens and vineyards. ${ }^{3}$ These measures had long-term effects. What had been an important area for commerce became an economically and culturally neglected zone. Settlements around the lake were isolated by the border defenses and military reservations located in or nearby them. ${ }^{4}$ Not just the land itself was neglected and negatively depicted in the Hungarian media. Local residents were accused of being spies or cross-border collaborators. ${ }^{5}$ People who received government permission to visit Sopron, a major nearby city, were not allowed to visit the region that eventually became the Fertő/Neusiedlersee UNESCO World Heritage cultural landscape. It was all but impossible for anyone to get close to the lake or to neighboring settlements such as Fertórákos. Running water was not introduced in many settlements until 1971, which indicates how neglected the region and its inhabitants were. ${ }^{6}$

The situation changed over the decades. Notably, in 1965 a new electronic signaling system for border protection was introduced. It provided sound and light signals on the spot of violations and notified border guard units when anybody or anything crossed the border. Even though this system was not designed to kill trespassers, it still defined the atmosphere of the region and the everyday life of the locals. By the 1980s, this "gentle Iron Curtain" proved to be both inefficient and outdated, because it frequently reacted to animals crossing the border. Moreover, it became increasingly unnecessary in the light of political changes in Hungary and internationally. These changes were heralded by Soviet leader Mikhail Gorbachev's address to the United Nations in 1988, in which he announced a drawdown of the Soviet military presence in Warsaw Pact countries. Other changes included the freer issuance of passports to Hungarians beginning the same year, which provided them with a limited possibility of travel to Western countries. The political leadership decided to dismantle the signaling system and increased the number

2 György Molnár, “Megszállók homályban,” Beszélő 1, No. 8 (1996): 36-46.

3 Tibor Zsiga, A "vasfüggöny" és kora / Der Eiserne Vorhang und seine Zeit (Budapest: Hanns Seidel Alapítvány, 1999), 70-78.

4 Miklós Zeidler, “Társadalom és gazdaság Trianon után,” Limes 2 (2002): 5-24.

5 Ferenc Jankó and Imre Tóth, “Az osztrák-magyar határtérség történelme és politikai földrajza,” in Ausztria a 20. században. Az "életképtelen" államtól a "boldogok szigetéig”: Tanulmányok, ed. István Németh and Róbert Fiziker (Budapest: L'Harmattan Kiadó, 2011), 377-403.

6 József Hárs, Fertörákos. Száz Magyar Falu Könyvesháza (Budapest: Arcanum, 2000), 88. 
of border crossing points. ${ }^{7}$ Hungary's political changes in 1989, its accession to the European Union in 2004, and its inclusion into the Schengen area in 2007 motivated further cross-border cooperation with Austria.

The lake region became popular for tourism in the 1990s, but the economic and recreational boom that change brought did not last very long. ${ }^{8}$ The western part of Hungary is considered more developed than its eastern part in the public consciousness. ${ }^{9}$ However, research and interviews conducted in the region contradict that view. Settlements around the lake experienced economic disadvantages because many local residents found employment in neighboring Austria and hence did not contribute much to the local economy. ${ }^{10}$ On the other hand, Austrians often bought empty houses in the region and used them as summer residences. Based on on-site interviews, that trend did little to energize the settlements' economic situation or their local community life. ${ }^{11}$ Transportation was still problematic, and tourists had difficulty reaching the lake region into the mid-2010s.

The Austrian side of the lake began to develop as a tourist destination as early as in the late 1970s. ${ }^{12}$ The Hungarian side was rather a destination for biologists and environmental specialists, because there the lake and its immediate surrounding was not as attractive for leisure. ${ }^{13}$ Environmental tourism was the only viable development option in the region, but in Hungary that was not widely sought after or established until the late 2010s. Even in the mid-2010s and after, Hungary's national development plans encouraged municipalities to invest in water sport facilities, cultural tourism, and business travel and paid much less attention to environmental tourism. For example, 16 billion Hungarian forints were granted to support inner-city improvements in Sopron, including a conference center for 1200 people. Only about 8.5 billion forints were granted for things such as bicycle paths and spas. ${ }^{14}$

7 János Sallai, 20 éves a határnyitás. A vasfüggöny léte és vége (Budapest: Hanns Seidel Stiftung, 2009), 1-53.

8 "Unemployment rate by age groups and gender between 1992 and 2016," Hungarian Central Statistics Office, https://www.ksh.hu/docs/hun/xstadat/xstadat_hosszu/h_qlf012a.html.

9 Pál Belyó, "Magyarország 1989-2009: A változások tükrében” (Budapest: Központi Statisztikai Hivatal, 2010), https://www.ksh.hu/docs/hun/xftp/idoszaki/mo/mo1989_2009.pdf.

${ }^{10}$ Mónika Freid and Gyula Holka, "A társadalmi-gazdasági változások néhány vonása az elmúlt 20 évben (1989-2009)," Statisztikai Szemle 89, No. 1 (2011): 20-49.

${ }^{11}$ Interviews conducted by the author at the open-air museum in Sarród in July 2015 and with local mayors of Fertőhomok in August 2018.

12 Promotion of tourism at the Neusiedlersee can be exemplified by the slogan used in tourist posters, “The Sea of the Viennese.” See Sándor Békési, “Fenséges pocsolya: A Fertő. Egy táj kultúr- és szemlélettörténetéról," Soproni Szemle 63, No. 2 (2009): 188-208, 202.

13 Zoltán Rakonczay, A természetvédelem története Magyarországon, 1872-2002 (Budapest: Mezőgazdasági Kiadó, 2009), 145-180.

14 “1862/2016. (XII. 27.) Korm. határozat a Sopron-Fertő kiemelt turisztikai fejlesztési térség meghatározásáról és a térségben megvalósítandó egyes fejlesztések megvalósításához szükséges források biztosításáról,” Magyar Közlöny, December 27, 2016, 84192, http://www.kozlonyok.hu/ nkonline/MKPDF/hiteles/mk16217.pdf. 
Based on observations at the time, the settlements in the region had numerous empty, deteriorating houses - many with former military functions - which gave the impression of a lonesome, deserted territory, just like the borderland was in the Cold War period. The situation of the formerly military buildings was usually complicated by their ill-defined, complex ownership status. ${ }^{15}$ That made it impossible to quickly decide their fate. Prolonged negotiations contributed to their deterioration and the alienated impression they gave, even in the early 2000s. Legal issues usually had to be resolved at the highest level between local municipalities and central government institutions. Because most of the former military and border guard buildings and properties were owned by state, the Hungarian National Asset Management corporation has been the primary decision-making unit of the central government in this case.

Some new border-crossing points were established after 1989 with state and international financial support, such as the one at Sopronkövesd in $2005 .{ }^{16}$ Cultural events were sponsored by neighboring foreign cities, like a photo exhibition about Eisenstadt, Austria that was held in Sopron in 2010. ${ }^{17}$ Moreover, increasing traffic through the region and the various restrictions defined by diverse international cultural and environmental protection organizations prevented the region's residents' feelings of isolation. Despite all the challenges, the population in most of the settlements increased after the area received its recognition as a UNESCO World Heritage site. There was only one exception: Sarród, where the population decreased between 2001 and 2015. That suggests a lack of understanding of the territory at the local and national levels and disagreement about its present and future course as well. Even though positive changes can be identified in the recent past, like the construction of a new highway, the area is still not well-served by mass transport. Detailed analysis of the region's opportunities for development needs further research. Projects are ongoing at both the local and national levels.

The following report is based on field research in the Fertö/Neusiedlersee cultural landscape conducted as a part of the author's PhD dissertation. ${ }^{18}$ The research analyzed the introduction of the concept of "cultural heritage" in Hungary. It was intended to determine how the image of a specific region has changed as a result of "heritagization."

15 Miklós Gosztonyi, “Parkolópályán az igényelt ingatlanok,” Kisalföld, May 28, 2014.

16 "Készül a határátkelő Sopronkövesden," Kisalföld, July 18, 2005.

17 “Eisenstadti fotókból," Kisalföld, February 8, 2010.

18 Melinda Harlov-Csortán, "The introduction of the notion of cultural heritage and heritagization in Hungary (1957-2015). Critical analysis of Hollókő and Fertő / Neusiedlersee through the lens of heritagization" (Doctoral Dissertation, Eötvös Loránd University, Budapest, 2021). Other publications drawing on the research include Melinda Harlov-Csortán, "From Environmentalised Heritage to Heritagised Environment: The Case of the Reedland at Fertö / Neusiedlersee," in Heritage and Environment, 5th Heritage Forum of Central Europe, ed. Agata Wąsowska-Pawlik and Jacek Purchla (Krakow: International Cultural Centre, 2021), 139-154; Melinda Harlov-Csortán, "From the Borderland of the Iron Curtain to European and World Cultural Heritage," Folklore. Electronic Journal of Folklore 70 (2017): 193-224, doi: 10.7592/FEJF2017.70.harlov_csortan; and Melinda Harlov-Csortán, "A cultural landscape on the border," in Proceedings of TCL 2016 Conference. Tourism and Cultural Landscapes: Towards a Sustainable Approach, ed. Lia Bassa and Ferenc Kiss (Budapest: INFOTA, 2016), 229-240. 
Heritagization is a word coined to describe the complex process of achieving and maintaining heritage status. It refers to the identification, maintenance, safeguarding and popularization of any kind of heritage. This report provides information about diverse but still not totally effective memory techniques between 1989 and 2015 to preserve the memory of the traumatic Cold War past in the Fertő/Neusiedlersee cultural landscape. It introduces a core narrative as well as a handful of examples of memorializing certain moments and aspects of the Cold War period in the region. It also identifies reasons why these efforts have been ineffective in memorializing the Cold War past.

\section{Protecting a Transborder Site But Not its Cold War Past}

The Fertö/Neusiedlersee UNESCO World Heritage cultural landscape is located on both sides of the former Iron Curtain. It is not unique as a protected territory straddling an international border. The International Union for Conservation of Nature (IUCN) has been dealing with such situations since 1988, when it organized the first workshop entitled Border Parks. Since then, transboundary protected areas have become the subject of a worldwide network of experts and specialists that works "to promote and encourage transboundary conservation for the conservation of nature with associated ecosystem services and cultural values while promoting peace and co-operation among nations, through enhancing knowledge and capacity for effective planning and management of transboundary conservation areas." ${ }^{19}$ The Fertö/Neusiedlersee cultural landscape has been recognized by the IUCN since 1991 as a Transboundary Protected Area. This designation means that it is a "clearly defined geographical space that includes protected areas that are ecologically connected across one or more international boundaries and involves some form of cooperation." ${ }^{20}$

The EUROPARC Federation, established in 1973, focuses its efforts on the cultural and natural heritage of Europe. It launched a program on transboundary parks in 2003 and named the Austrian and Hungarian national parks around Lake Fertö/Neusiedler as one of its first projects. This international organization arranges reviews of its member organizations regularly. The two national parks of the lake region, the Fertő-Hanság National Park and the Neusiedlersee Seewinkel National Park, were positively reviewed in 2010 and 2015. ${ }^{21}$ Similarly, the UNESCO World Heritage Committee pays attention to transborder examples of World Heritage sites. ${ }^{22}$ By 2015, thirty-three of the 1,031 UNESCO World Heritage sites

${ }^{19}$ IUCN World Commission on Protected Areas, Transboundary Conservation Specialist Group, “Terms of Reference. Strategic Directions 2009-2012," 2, https://www.tbpa.net/docs/1a IUCN\%20WPCA\%20Transboundary\%20Conservation\%20Specialist\%20Group\%20TOR\% 20 -\%20Final\%20-\%20Oct\%201\%202009.pdf.

20 "Typology of Transboundary Conservation Areas - 2011," Global Transboundary Conservation Network, http://www.tbpa.net/page.php?ndx=83\#1.

21 “Transboundary Network," EUROPARC Federation, https://www.europarc.org/about-us/network/transboundary-network/.

22 Transnational UNESCO World Heritage sites have their own separate category in the UNESCO World Heritage inventory, https://whc.unesco.org/en/list/\&\&transboundary=1\&order=year. 
were transboundary in nature. In 2001, the Fertö/Neusiedlersee UNESCO World Heritage cultural landscape was the seventh such transboundary heritage site recognized by the UNESCO World Heritage Committee. The variety of territories protected by these supranational organizations and their designations show that transboundary protected territories are not unique to Austria and Hungary.

Despite their complexity, the events of the last century did not play an essential role in the nomination of the lake region for heritage status, or in the supplementary and evaluation documents submitted in support of it. The two advisory bodies of the UNESCO World Heritage Committee, the International Council on Monuments and Sites (ICOMOS) and the International Union for Conservation of Nature (IUCN), focused more on the prehistoric past of the Fertő/Neusiedlersee cultural landscape. ${ }^{23}$ In the sixty pages of supporting documents, only two paragraphs speak of the region's twentieth century past. One reason for this may be that in general the important historical sites of the twentieth century are rather underrepresented on the UNESCO World Heritage List. Even though "socialist heritage" and "dissonant heritage" are recognized concepts in academic discourse, areas with such importance have rarely become UNESCO World Heritage sites.

ICOMOS started the discussion of the heritagization of sites of twentieth century importance in the 1980s in its publications, national committee workshops, and expert meetings, mainly in terms of the conservation of protected architecture. ${ }^{24}$ It created an action plan, the Montreal Action Plan, in $2001 .^{25}$ It also established a designated expert group, the ICOMOS International Scientific Committee on Twentieth Century Heritage, in 2005 and conducted an analysis of gaps in the World Heritage List. ${ }^{26}$ Since then, ICOMOS has paid special attention to examples of the heritage of the twentieth century. When the Fertő/Neusiedlersee cultural landscape was included on the UNESCO World Heritage List in 2001, the heritagization of twentieth century sites had not yet fully developed on the international level. Even in 2020, there were only forty-one UNESCO World

23 Bundesdenkmalamt and VÁTI, Documentation for the nomination of the Cultural Landscape of Fertö-Neusiedlersee Lake (Vienna and Budapest, 2000); VÁTI, Supplementary documentation for the documentation for the nomination of the cultural landscape of Fertö-Neusiedler Lake (Vienna and Budapest, 2001).

24 Anja Kervanto Nevanlinna, ed., Dangerous Liaisons: Preserving Post-War Modernism in City Centers (Helsinki: ICOMOS Finnish National Committee, 2001). The German National Committee of ICOMOS organized a conference in 1996 in Leipzig on the conservation of modern architecture with the title Konservierung der Moderne? Conservation of Modern Architecture? Über den Umgang mit den Zeugnissen der Architekturgeschichte des 20. Jahrhunderts. An example of an expert meeting on twentieth century tangible heritage is the ICOMOS Seminar on 20th Century Heritage on June 18-19, 1995 in Helsinki, Finland, http://www.international.icomos.org/20th_ heritage/helsinki_1995.htm.

25 “The Montreal Action Plan," International Council on Monuments and Sites, https://www.icomos.org/20th_heritage/montreal_plan.htm.

26 "The World Heritage List. Filling the Gaps: An Action Plan for the Future," International Council on Monuments and Sites, https://www.icomos.org/en/about-icomos/image-menu-about-icomos/116-english-categories/resources/publications/258-monumentsasites-xii. 
Heritage sites that were built in the twentieth century. ${ }^{27}$ Even fewer sites have been recognized for their tragic historical significance, among them Auschwitz-Birkenau, German Nazi Concentration and Extermination camp (1940-1945) (named to the list in 1979), the Hiroshima Peace Memorial (Genbaku Dome) (named in 1996), and the Bikini Atoll Nuclear Test Site (from 2010). The small number of such sites suggests that the recent past was not considered to have much heritage value on the supranational level until the early 2000s. It was at that time that the UNESCO World Heritage Committee recognized Lake Fertö/Neusiedler as a cultural landscape.

On the national level in Hungary, there has been significant recent support for the cultural heritage value of the lake region. Unfortunately, it has been expressed in focused, top-down initiatives that did not recognize or manage the complexity of the Fertö/Neusiedlersee cultural landscape. In Hungary, targeted financial support has come mainly from the state and to a lesser extent from the European Union. In the first decade after Hungary's accession to the EU, funding was allocated for example to the Esterházy palace, a former noble estate in Fertőd, along with its connected buildings and its garden. This cultural site was transformed into a museum at the end of the Cold War period, but its significance began to increase immensely after its inclusion as part of the UNESCO World Heritage cultural landscape in 2001. The palace was designated by the Hungarian government as a historic memorial place in 2011, emphasizing that it "represent[s] important Hungarian historical moments." 28

The case of the Esterházy palace is interesting from the perspective of the lack of memorialization of the Cold War period. Even though the last living member of the Esterházy family, Prince Antal, has been living there since 2014 as a representative of the latest period in the family history, most of the building serves as a museum of the eighteenth century past and as an event venue. The heritagization of the Esterházy palace, with its overall emphasis on its aesthetic value and the paucity of information presented about its history close to the Iron Curtain, illustrates how the Cold War has generally been ignored in the historical representation of the lake region.

\section{Memorialization of Specific Events of the Cold War Period}

The 1956 Revolution and the Fight for Freedom

The Fertő/Neusiedlersee cultural landscape has a very complex past and witnessed numerous moments and periods in the twentieth century that deserve to be memorialized. Major historical events include significant changes in the local population during and after

27 "Built in the 20th century," World Heritage Site, https://www.worldheritagesite.org/connection/ Built+in+the+20th+century.

${ }^{28}$ National Heritage Institute, http://nori.gov.hu/tortenelmi-emlekhelyek/Fertod/fertod-esterhazy-kastely/. 
World War II. In the wake of the 1956 Revolution and Freedom Fight, some 150,000 to 200,000 Hungarians escaped to the West through the territory. ${ }^{29}$ This flow of people played an important part in Austrian history as well. ${ }^{30}$ The hosting of escaped Hungarians is an important element in the self-image of the Austrian border state of Burgenland. ${ }^{31}$

Before the political changes of 1989, commemoration of certain historical events such as the 1956 Revolution and Freedom Fight, and in fact any critical analysis of the past, were challenging acts in Hungary. ${ }^{32}$ After 1989, commemoration of the 1956 events often involved the inauguration of new physical memorials. These examples of public art can be found in almost every Hungarian settlement and have some common features and characteristics. The author's on-site research showed that memorials in the Hungarian part of the Fertö/Neusiedlersee cultural landscape share certain national features, but do not allude to any aspect of the specifically local past. Even the famous bridge at Andau, across which people left the country for Austria, can easily be reached only from the Austrian side of the border. A whole set of memorials and information boards reflect international and Austrian initiatives to commemorate the 1956 events. There is nothing similar on the Hungarian side of the Einser Canal along the border. ${ }^{33}$ There have been some important scholarly initiatives in Hungary, such as an oral history project of the Open Society Archives that recorded the inhabitants' memories of the 1956 events in the region, but there is little or no sign of them on the ground. ${ }^{34}$

The Fertő/Neusiedlersee cultural landscape was conceived as a bridge for overcoming the separation between East and West, but its heritagization has been a slow process. To prevent its history from being forgotten, there have been a few attempts to develop a new type of tourism. Such tourism targets locations of importance to the relatively recent past in order to preserve and share the local memory of it. For instance, an Iron Curtain bike route has been established and promoted. This route is part of the EuroVelo13 bike path (the Iron Curtain Trail), which stretches 10,000 kilometers from the Barents Sea to the Black Sea. In Hungary, it leads through less touristed but historically

${ }^{29}$ János Sallai, Egy idejét múlt korszak lenyomata A vasfüggöny története (Budapest: Hanns Seidel Stiftung, 2012), 42.

30 Michael John, "Migration in Austria. An overview of the 1920s to 2000s," in Understanding Multiculturalism. The Habsburg Central European Experience, ed. Johannes Feichtinger and Gary B. Cohen (New York: Berghahn Books, 2014), 123-150.

31 Sándor Békési, Verklärt und verachtet: Wahrnehmungsgeschichte einer Landschaft: Der Neusiedler See (Wien: Peter Lang, 2007).

32 Attila Pók, Remembering and Forgetting Communism in Hungary. Studies on Collective Memory and Memory Politics in Context (Köszeg: IASK, 2017), 208-215.

33 Regarding the still existing boundary between the two countries, see Gerhard Baumgartner, Éva Kovács, and András Vári, Távoli szomszédok. Jánossomorja és Andau 1990-2000 (Budapest: Teleki Alapítvány, 2002).

34 “Transnational Memories - Hungarian Refugees in 1956," Vera and Donald Blinken Open Society Archives at CEU, http://www.osaarchivum.org/podcast/episode1_transitional-memories_hungarian-refugees-in-1956. 
relevant areas. ${ }^{35}$ Whether such a project can capture the significance of this territory during the Cold War period is a subject for future research, which would look at the popularity of the bike path project, the complexity of the audience it targets, and its effect on the formation of a local identity.

\section{The Pan-European Picnic of 1989}

In 1989, the northern end of the border zone between Austria and Hungary played a significant role in the history of the two countries. The Pan-European Picnic, which was held on August 19, 1989, was organized in a meadow close to Lake Fertö/Neusiedler. Music, bonfires, and dancing took place directly next to the border to express a demand for the unification of Europe and the elimination of the Iron Curtain. Due to rumors that the border would be opened and the slogan for the event, "break it and take it!," which referred to the border fence, hundreds of people with East German origin came to the event. They believed the border would open and they could get to Austria and request West German resident permits. Even though the original plan did not in fact include the opening of the border, in the event the Hungarian border guards could not peacefully stop the mass of people from doing just that. The border guards decided not to employ violence and about 600 people passed through into Austria. ${ }^{36}$ The Pan-European Picnic is memorialized in Hungarian public discourse as the first step, and a peaceful one, toward the fall of the Iron Curtain. ${ }^{37}$

That same year, the organizers of the event decided to establish a private foundation to protect the memory of the grassroots, peaceful event that contributed to the elimination of the Iron Curtain. They have organized yearly commemorations and guided tours of the Pan-European Picnic Memorial Park established at the site. ${ }^{38}$ Since the park gained its cultural function, the number of public artworks displayed there has multiplied. The tangible signs of pre-1989 border control, such as a watchtower, became memorials that add to the experience of a visit and to understanding of the event. The new memorial artworks are mainly gifts from diverse communities that honor the original event. The monuments are of very different characters, sizes, materials, etc. Each one influences the interpretation of the others and of the memorial park itself. In 2019, a member of the foundation management spoke with the author about its growing international network of contacts with institutions and organizations that share a similar focus. For example, the Pan-European Picnic

35 See the official website of the European Green Belt Association, http://www.europeangreenbelt. org/, and the website operated by the European Cyclists' Federation, http://www.eurovelo13. com/. See also Michael Cramer, Iron Curtain Trail Part 3: Along the "Green Belt" from the German-Czech Border to the Black Sea (Berlin: Esterbauer, 2010).

36 András Oplatka, "The Pan-European Picnic - well-known facts and blind spots," in Prelude to demolishing the Iron Curtain, ed. György Gyarmati (Budapest: L’Harmattan, 2012), 65-72.

37 Gyula Kurucz, ed., Az első határnyitás: Sopron, 1998. augusztus 19. (Budapest: Kortárs Kiadó, 2000), 50-58.

38 Interview conducted by the author with the president of the foundation, Dr. László Magas, in 2016. 
Memorial Park is strongly connected to the European Solidarity Centre in Gdańsk, Poland. Both received the European Heritage Site label from the European Commission in 2014. ${ }^{39}$ Interestingly, a visitor center with exhibition and information materials about the original event as well as a small refreshment area was only established as of the thirtieth anniversary of this historical event in 2019. Unfortunately, with the increasing number of new monuments at the site the authentic appearance of the place is threatened. ${ }^{40}$

The yearly commemorations, the individual visits by curious tourists, and the heritagization of this local event attest to the significance of the place of the Picnic. Although it memorializes only a part of the Cold War period - its ending - it nevertheless deserves to be included in the territory recognized by the UNESCO World Heritage Commission. Interestingly, neither the Pan-European Picnic Memorial Park, nor the events it commemorates, have become part of either the core or the buffer zone of the Fertö/Neusiedlersee UNESCO World Heritage cultural landscape. The historical event is however mentioned in the UNESCO nomination document and in the evaluation by ICOMOS with the same statement: "It was at Fertőrákos, 'the place where the first brick was knocked out of the Berlin wall,' that participants at a Pan-European Picnic tore down the barbed wire and re-opened the frontier which still crosses the Lake." ${ }^{41}$ The Management Plan for the UNESCO site from 2003 recommended that the World Heritage site be expanded "up to the road leading to the Pan-European Picnic site" and identified the yearly commemoration of the Picnic as a major program in the region. 42

The same can be said about the settlement of Andau, which played an important role after the revolution of 1956. However, Andau lies approximately ten kilometers from the edge of the UNESCO site's buffer zone; the Memorial Park is only one kilometer away. The fact that neither the local celebrations nor the tangible evidence of the Cold War period - at the Pan-European Picnic Memorial Park or at Andau - have officially undergone the heritagization process expresses a strong stand by the powers that be on their evaluation of that time in history.

\section{Memorialization of the Cold War Period through Public and Private Initiatives}

Diverse techniques are in use on the Hungarian side of Lake Fertő/Neusiedler to memorialize the Cold War period. Two small museums in Felsőcsatár and Fertőrákos

39 “European Heritage Label sites," European Commission, https://ec.europa.eu/culture/cultural-heritage/initiatives-and-success-stories/european-heritage-label-sites.

40 On events held at the Pan-European Picnic Memorial Park, see the website operated by the municipality of Sopron city, http://www.paneuropaipiknik.hu/index.php?site=50.

${ }^{41}$ Bundesdenkmalamt and VÁTI, Documentation for the nomination, 30 and ICOMOS, Advisory body evaluation of Fertő / Neusiedlersee nomination (November 2001), 2, https://whc.unesco. org/en/list/772/documents/.

42 Stadtland and VÁTI, Fertö-táj kulturtáj - világörökség kezelési terve, 10, 118, http://www.fertotaj. $\mathrm{hu} /$ document/kezelesi_terv.pdf. 
have been established and managed by former border guards. ${ }^{43}$ These private museums describe the border protection system used at that time and the life of the border guards. The museums present the personal viewpoints of their owners and are based on the materials available to them. From on-site research and interviews with the owners it can be said that their museums have no connection with or acknowledgement from other museums or government cultural authorities. Due to their limited financial, human, and professional resources, they are unable to attract a significant number of visitors. ${ }^{44}$ Despite all the challenges, the museums provide visitors with interesting personal narratives that enrich the broader local narrative about the recent past. Even if they only relay first-hand experiences, their contribution should not be underestimated..$^{45}$

A technique similar to the public art dedicated to the 1956 Revolution and Freedom Fight has been used to memorialize the Iron Curtain in the village of Hegykö. This is an open-air memorial located next to the settlement, exactly where the actual fence line used to be. Remaining elements of the old border protection system are maintained together with information boards in Hungarian and English that were erected in 2008 by the local municipality. As of the mid-2010s, the site of the memorial seemed rather abandoned, not just because of its location in the midst of agricultural fields, but also because of a lack of signage or other information directing visitors to it from within the village of Hegykö. ${ }^{46}$

The difficulty in accessing the memorial site can be justified by the concept of genius loci, or the spirit of a place..$^{47}$ This concept has existed since the first studies of the built environment. The genius loci consists of the given location, the political, historical, and cultural surroundings, and a kind of value-laden, symbolic experience. ${ }^{48}$ Accordingly, the genius loci can be understood as a tool for connecting intangible values and tangible

43 "Iron Curtain Museum Felsőcsatár," https://vasfuggonymuzeum.hu/en/news and http://www. fertorakosikirandulas.hu/fertorakos/vasfuggony_muzeum.html.

44 The author conducted interviews with both owners on numerous occasions between 2016 and 2018.

45 Daniel L. Schacter, Scott A. Guerin, and Peggy L. St. Jacques, "Memory Distortion: An Adaptive Perspective," Trends in Cognitive Sciences 15, No. 10 (2011): 467-474, doi: 10.1016/j. tics.2011.08.004.

${ }^{46}$ András Keszei, Emlékek formájában. Egyéni, társadalmi és kulturális hatások a múlt felidézésében (Budapest: L'Harmattan Kiadó, 2015), 10-18.

47 The concept of genius loci has been adopted by diverse research perspectives. There are researchers who instrumentalize the concept when they emphasize locations. See Gordon Cullen, The Consise Townscape (London: Architectural Press, 1961), 9. Others use it when they give attention to the receiving/understanding process. See Claude Moulin, "On concepts of community cultural tourism," Revue de Tourisme - The Tourist Review 50, No. 4 (1995): 37. The analysis of genius loci can focus on the local population (see Tuan Yi-Fu, Space and Place (London: Edward Arnold, 1977)); visitors (see John A. Jakle, The Visual Elements of Landscape (Amherst: University of Massachusetts Press, 1987), 8); a group or community (see Dolores Hayden, The Power of Place: Urban Landscapes as Public History (Cambridge: MIT Press, 1995)), or individual initiatives. All these aspects are interrelated and underline the plural and dynamic aspects of the concept.

${ }^{48}$ Heather Skinner, "In search of the genius loci: The essence of a place brand," The Marketing Review 11, No. 3. (2011): 281-292, doi: 10.1362/146934711X589471. 
heritage elements. It was officially defined in 2008 in the Québec Declaration on the Preservation of the Spirit of Place, which identified it as "the tangible (buildings, sites, landscapes, routes, objects) and the intangible elements (memories, narratives, written documents, rituals, festivals, traditional knowledge, values, textures, colors, odors, etc.), that is to say the physical and the spiritual elements that give meaning, value, emotion and mystery to place." 49 The interconnectedness of the material and the social aspects of heritage exists despite the differentiation between examples of intangible and tangible heritage. ${ }^{50}$ The memorial at Hegykő is located where the Iron Curtain used to be and is assumed to have significant meaning for visitors. The closeness of the border fence to the settlement, as well as its "disturbing" of the traditional agricultural activities that used to take place there, implicitly emphasizes the emotional understanding of the place.

Failure to deal with the recent past can have a multi-layered effect on people. On the one hand, by neglecting to memorialize certain aspects of the past, the memory of the Soviet period and the identity of the local population as Central or Eastern Europeans are undermined. Forgetfulness of the past is especially common among the younger generation, who do not have personal memories of those times. ${ }^{51}$ On the other hand, by not dealing with the recent past change cannot be realized and local residents will continuously feel that they are living on the periphery of the country, just as they did when they lived in the shadow of the Iron Curtain. The variety of memorial techniques that address the previous political system enrich the Fertő/Neusiedlersee cultural landscape because they describe and interpret almost half a century of history from multiple perspectives. One reason for the lack of public knowledge about the personal museums and the examples of material heritage in the area is their lack of connection and widely dispersed locations within the cultural landscape. Connecting them with a road or path similar to the Iron Curtain bike route might solve this problem. An umbrella organization and the cooperation of diverse actors, including private organizations and municipalities, would be necessary for success.

\section{Conclusion}

The circumstances, living standards, and restrictions on liberty imposed on Hungarians during the Cold War period, especially in the direct proximity of the Iron Curtain, cannot be forgotten or forgiven easily. ${ }^{52}$ The violations of human rights are still within

49 UNESCO, Québec Declaration on the Preservation of the Spirit of Place (Adopted at Québec, Canada, October 4, 2008), 2, https://whc.unesco.org/uploads/activities/documents/activity-646-2.pdf.

50 UNESCO, Convention for the Safeguarding of the Intangible Cultural Heritage (Adopted in Paris, France, October 17, 2003), https://unesdoc.unesco.org/ark:/48223/pf0000132540.

51 Justinian A. Jampol, "Smashing Lenin Won't Save Ukraine," The New York Times, March 3, 2014, http://www.nytimes.com/2014/03/04/opinion/smashinglenin-wont-save-ukraine.html.

52 Katalin Verdery, The Political Lives of Dead Bodies: Reburial and Postsocialist Change (New York: Columbia University Press, 1999), 85. 
living memory because of the closeness of that time period to the present. They still have physical manifestations today, more than a quarter of a century later, in the form of the bombs and other weapons from World War II and the Cold War period that are still occasionally found in the lake and around it. ${ }^{53}$ The consequences include the transformation of the natural environment as well; more precisely, in the increase of grasslands, marshes, fallow land, and woods after the border was closed. Yet despite the multilevel, long-lasting local influence of the Cold War on the area, its significance has not been recognized in the heritagized history of the Fertő/Neusiedlersee cultural landscape.

One possible reason that significance has been neglected is the timing of the UNESCO nomination and the fact that it was proposed by two State Parties with significantly different historical pasts on opposite sides of the Iron Curtain. After the political changes in Hungary in 1989 and especially in the drive to join the European Union in 2004, academic and political narratives insisted that Hungary always was and still is a fully European country. Accordingly, the Soviet period was viewed as an insignificant rupture in the flow of the country's entire history. ${ }^{54}$ The almost two-year-long ( January 1, 2000 to August 20, 2001) nation-wide celebration of the thousandth anniversary of Hungary's adoption of Christianity and the creation of the Hungarian state reflected that conviction. ${ }^{55}$ The representatives of the two states, Austria and Hungary, that formulated the nomination documents for UNESCO world heritage site status (the Bundesdenkmalamt and VÁTI, respectively) preferred to highlight the thousand years of their common legacy rather than the approximately forty years that "interrupted" that continuum. Another concern of the nominating agencies was emphasizing (perhaps to an extreme) the Central European-ness of the territory. They cited typically Central European characteristics of the Fertö/Neusiedlersee cultural landscape such as the diverse nationalities of its inhabitants, its rich culture, and its social and economic structures. ${ }^{56}$ This concern may have motivated them to downplay the Iron Curtain past of the region in the heritagization narrative they presented on the national and international levels. ${ }^{57}$

53 Miklós Gosztonyi, "Repeszgránátot emeltek ki a Fertő tóból," Kisalföld, November 29, 2017.

${ }^{54}$ László Péter, "Central Europe and its reading into the past," European Review of History 6, No. 1 (1999): 101-111, doi: 10.1080/13507489908568224.

55 The UNESCO World Heritage Committee held its annual event in Budapest at that time. The Fertő/Neusiedlersee cultural landscape was then added to the UNESCO World Heritage List.

56 The characteristics of Central European-ness are expressed by Miłobędzki as "the prevailing agricultural economy, the diverse development of urbanization [there are villages as well as free cities with the right to organize markets, Rust on the Austrian side of the lake], the domination of the Catholic faith [since as early as the thirteenth century, based on the monument church in Hidegség].” See Adam Miłobędzki, "Central-Eastern Europe: Its cultural landscape and architectural coverage," in Heritage Landscape. Integrated Urban and Landscape preservation and restoration, ed. Maria Bogdani-Czepita (Krakow: International Cultural Centre, 1993), 38. For the debate on Hungary as Central or Eastern European, see also Ignác Romsics, "Közép -és/vagy Kelet-Európa?” in Közép-európai olvasókönyv, ed. Péter Módos (Budapest: Osiris and Közép-európai Kulturális Intézet, 2005), 27-38.

57 Jankó and Tóth, “Az osztrák-magyar határtérség," 377-403. 
Dealing with the Cold War period has been a task for many Central and Eastern European countries since the fall of the Iron Curtain, especially as they prepared themselves to enter the European Union. ${ }^{58}$ In most cases, they prefer to emphasize the historical periods before the second half of the twentieth century and represent them as golden ages. "Memorialization techniques" that recall the Iron Curtain period are sidelined in the process of heritagization and become secondary. ${ }^{59}$ The periods before and after the Cold War are represented as one continuous historical past. ${ }^{60}$ This is a conscious effort to justify the unification of the former communist countries with Western Europe. ${ }^{61}$

The silent spaces created around this traumatic period, for example in the missing memorial on the Hungarian side of the bridge at Andau, and the untold chapter in the history of the Esterházy palace in Fertőd, point up the painfulness of the memory of the Cold War. Nevertheless, there are some places in the Fertö/Neusiedlersee cultural landscape, including the private museums and memorials that speak of it. Among others, the remains of the former Iron Curtain defenses near Hegykő and the empty meadow near Sopronkőhida have been transformed and gained new functions as cultural sites and, in the case of the latter, become real tourist attraction. These places have adopted diverse approaches to preserving and sharing the memory of historical events. They use different sources and methods and focus on different time periods in the Cold War. Some of them exhibit original, tangible objects and provide guided tours. Some focus on particular events, activities, and professions; others do not offer a specific narrative and hence are open to diverse interpretations by visitors.

In the private museums and at the Pan-European Picnic Memorial Park, the memory of specific events is preserved and communicated mostly by the same people who were participants in the history. They intend to convey the original experience and send a message to the greater public and more importantly, to future generations. They want to form the collective memory and contemporary group identity by sharing their personal memories and creating collective experiences for visitors. Elsewhere, the original actors are less directly involved. For instance, the municipality of Hegykő does not offer guided tours and the information panels provide quite general information. So do the various 1956 memorials in the settlements around the lake. In sum, those who have established and are managing the memorials to the Cold War time in the Fertö/Neusiedlersee cultural landscape are employing a variety of memory techniques to achieve their aims.

58 Nadia Kaneva and Delia Popescu, "National Identity Lite: Nation Branding in Post-Communist Romania and Bulgaria," International Journal of Cultural Studies 14, No. 2 (2011): 191-207, doi: $10.1177 \% 2 \mathrm{~F} 1367877910382181$.

59 Craig Young and Sylvia Kaczmarek, "The Socialist Past and Postsocialist Urban Identity in Central and Eastern Europe: The Case of Łódź, Poland," European Urban and Regional Studies 15, No. 1 (2008): 53-70, doi: 0.1177/0969776407081275.

60 Verdery, "The Political Lives of Dead Bodies."

${ }^{61}$ Duncan Light, "'Facing the future': tourism and identity-building in post-socialist Romania," Political Geography 20, No. 8 (2001): 1053-1074, doi: 10.1016/S0962-6298(01)00044-0. 
In the course of its heritagization, the Fertö/Neusiedlersee cultural landscape has experienced a kind of simplification and universalization of its cultural values. A shift from emphasizing the peculiarities of the region to a more generalized narrative for a greater international audience is ongoing. As Attila Pók pointed out: "The grand narratives of the past often conceal or blur the distinctive memories and understandings of history with regard to smaller regions, local communities and various social groups." ${ }^{62}$ That is why the involvement of multiple actors, attention to a multiplicity of values, and diverse narratives are so necessary in the heritagization process of the Fertö/Neusiedlersee cultural landscape.

62 Pók, “Remembering and Forgetting," 21. 